\title{
Commonplace
}

\section{Making amends with memes}

\section{Viktor Chagas}

Published on: Aug 10, 2020

DOI: $10.21428 / 6 f f d 8432 . a c 155 a 53$

License: Creative Commons Attribution 4.0 International License (CC-BY 4.0). 
When it comes to media literacy, Brazil provides a unique case study. We consider ourselves the world champions of meme production. We take our in-jokes to the next level, and we are lavish in selfdeprecating humor. Despite social ills and inequalities, we take the popular proverb seriously when it says that laughing is the best medicine. We are proud of our humor and internet culture has only intensified it. Although there are no numbers to prove it, most Brazilian people believe that Brazil is one of the most prolific countries to create and share internet memes, especially the ones that replicate a genre of humor we generally define as "zuera", absolute mockery.

But at the same time, while we know how to laugh and to make others laugh, sometimes it feels like there is an increasing amount of Brazilian people who use humor not to amuse but to trample. And an even greater number of people who have difficulty grasping all the complex layers of meaning that humor sews. The result is the use of humor to support extremist speech or falsehoods and a huge group of people who are uncritically in tune with these perspectives. There are many hypotheses for this phenomenon. One of them is that it is the effect of a recent wave of politicization of emerging sections of the Brazilian population. But the fact is that sometimes one can find oneself in trouble when trying to distinguish what is and what is not a joke, ultimately leading to a profound difficulty in distinguishing fiction from reality. It is not that art imitates life, it is that Brazilians are so used to creating ridiculous situations to face the harshness of reality, that reality often seems ridiculous to us and we end up anesthetized instead of politically mobilized.

The boundaries between what is and what is not a joke have been tested daily by public authorities and extremist groups. When it comes to conservative and extremist messages, it has been common for intentions to be disguised, which Whitney Phillips and Ryan Milner call ambivalence, followed by an immediate retraction that appeals to the classic excuse that "it was just a joke". It is a well-recognized rhetorical strategy for conservative groups to hide behind a veil of play. So it becomes urgent to become critically equipped on how to demystify mischievous uses of play, particularly when considering how to respond to disinformation.

Following Tandoc, Jr. and colleagues, we can think of disinformation on two different levels. They argue that it is possible to analyze stories based either on their facticitylevel or their mischievous intention. These two vectors, they say, allow us to differentiate disinformation from merely humorous messages such as those from satirical websites like The Onion or its Brazilian equivalent Sensacionalista [Sensationalist]. That is, there are essentially two ways (or two endeavors) to distinguish information from disinformation, and subsequently joke from not-joke: the first is looking at the format and content-level (facticity) of the message, the second is looking at its stance (the intention). This dichotomy between intention and facticity is what this text is about. 


\section{Intention}

On October 8, 2018, during the electoral period in Brazil, then-candidate Jair Bolsonaro declared that a statement he proffered one year before, saying that he had four sons and the fifth time he faltered and got a daughter, was just a joke. And added that it was a men's joke. Needless to say that lots of farright memes still continue to be spread reiterating the sexist speech.

And his allies follow the same path. On September 2019, Paulo Guedes, Bolsonaro's Minister of Economy, came out in defense of Brazilian President amid the Amazon fires crisis, telling that French President Macron was riled up because his wife is ugly. Faced with a potential international incident, Guedes stepped back, classifying his words as a bad-taste joke. One more: on April 2020, former Minister of Education, Abraham Weintraub, tweeted a meme with a countrywide popular cartoon child character that is known for misspelling the letter $\mathrm{R}$ for $\mathrm{L}$, which also recalls the Chinese accent when speaking Portuguese. It was a provocation against China, which is accused of benefiting from the coronavirus crisis by some Brazilian authorities aligned with Bolsonaro's far-right populist discourse. The Chinese Ambassador confronted the Minister and the latter apologized, saying that it was not racism but a "light joke."

If one wants to understand these movements, one needs also to take notice of the following episodes where it can be seen how this behavior is, in a way, rooted in Brazilian culture. Judge Marília Castro Neves justified herself as telling a joke, after saying that former deputy Jean Wyllys should be murdered in a "prophylactic execution." She ultimately amended her statement by saying that "The problem of leftist parties is that they do not have sense of humor." The last one: a grandmother of a sixyear-old child said a video of the child's stepfather deliberately forcing the child to kiss a gun was just child's play. The grandmother insisted in her testimony to the police that there was no risk to the child and it was just an in-joke. 

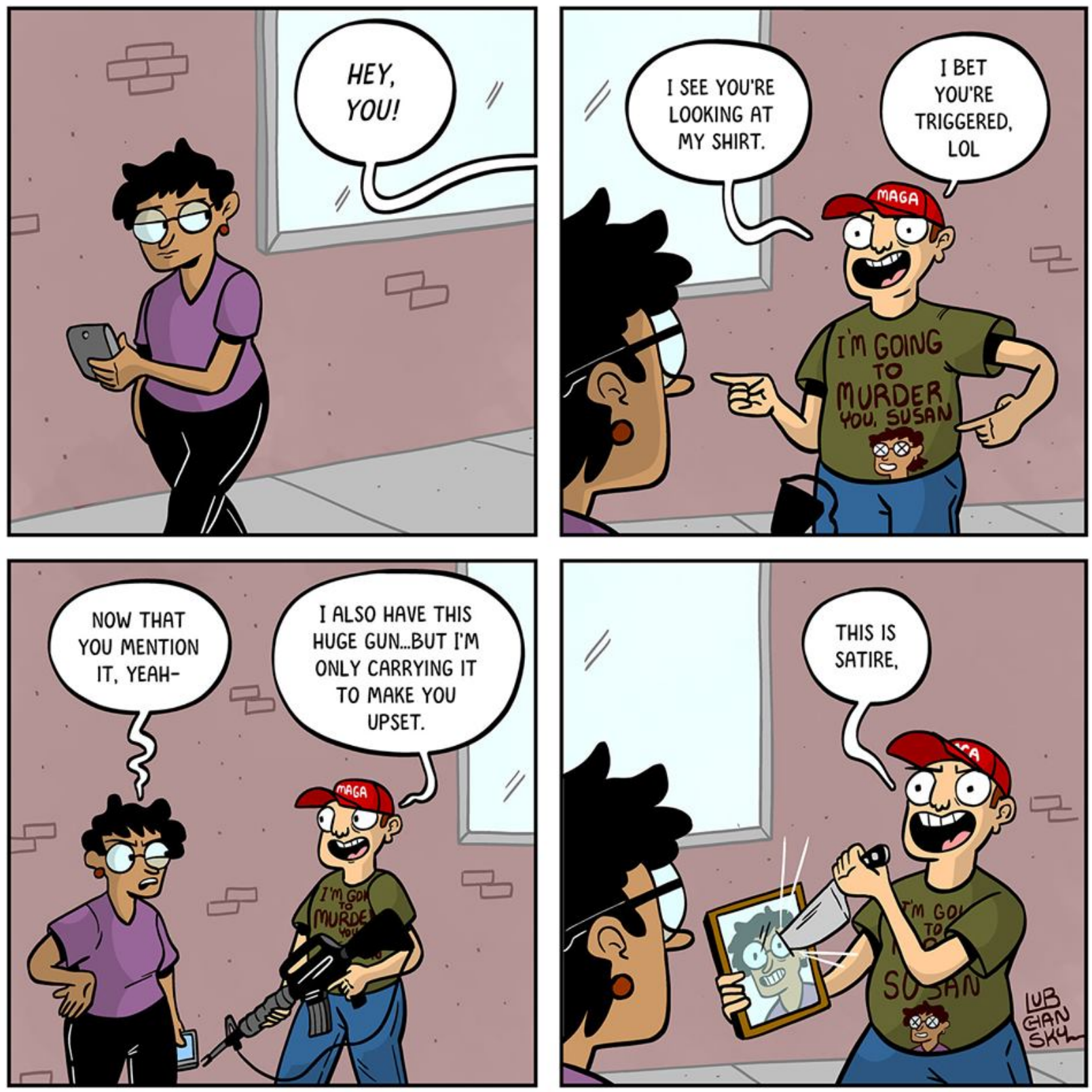

Figure: Threat Not

Source: Matt Lubchansky https://thenib.com/threat-not/?id=matt-lubchansky\&t=author.

All these episodes, of course, find similar examples in other countries. They are not exclusively Brazilian, although this kind of attitude has become uncomfortably common in Brazil, especially as formal responses in retractions by government officials. It simultaneously embodies a kind of normalization of harm (read political persecution, religious discrimination, sexism, racism, and other anti-democratic and even criminal attitudes) and a malicious attempt to key the communicative process a posteriori, as a way of justifying pushbacks. And most dangerous, in that succession of cases, is the frequency with which this justification has been assumed, which suggests a certain strategic 
behavior, that I have been designating as a rhetoric of play. This rhetoric adds to the three rhetorics of reaction originally identified by economist Albert O. Hirschman in his argument that historically reactionary forces have employed some patterned models of action in the hope of containing the expansion of rights or a change in status quo.

The three rhetorics Hirschman identifies are the perverse effect thesis, the futility thesis, and the threat thesis. The first postulates that changes generally generate effects contrary to those intended, the second states that every attempt to change the status quo is infertile, and the third affirms that people are somehow persuaded that there is a great menace lurking (like the Red Scare) every time there is a struggle for social change. I add a fourth thesis, called the rhetoric of play, which states that every time a group fights for their rights, a backlash movement seeks to disguise oppression in a playful way.

Rhetoric of play is possible whenever there is a noise in metacommunication, a noise, as Bateson would argue in one of his most prominent essays, that prevents observers from distinguishing between intentional and unintentional communication of play. So, following Whitney Phillips' concern in her introduction to Media Literacy_Toolkit series, we must be aware that one can have difficulties not only_ in telling what is and what is not fake but also in having the insight that the content should be fact checked or critically analyzed. In particular, we must be prepared to distinguish what is and what is not a joke. To do so, we must be equipped with tools that allow us to recognize and respond to metacommunication.

Hereupon it is important to state that humorous websites also benefit from the confusion of audiences in differentiating fact or fiction, and they are largely anchored in an emulation of the news format. As a result, one must be literate enough to decode the joke. It is not an easy task to recognize the "this is play" signs, as it comprises a keying process of frames. This reinforces the necessity of paying attention to a criterion that is not always easily discernible: the intention of a communication. For Goffman, the operation responsible for instilling traces of the intention of a message during a communicative act is known as "footing." Footing is an attempt to communicate the incommunicable, or, using the concept largely explored by Bateson, to metacommunicate.

Meta-communication is a device widely used by comedians who intend to tell audiences when or not to laugh about a joke, so that humor does not develop only through conversation in its explicit sense, but also largely by a dynamic interaction through social relations that establish and exchange meaning. But most of the studies dedicated to understand metacommunication processes focus on the sender of the message. Of course, the intention is, to a large extent, an ingredient resulting from what the sender wants to accomplish through that communication. But part of that process is notably decoded at the receiving instance. After all, I may not have intended to hurt, but I may have hurt nonetheless. Thus, play should always be read as an intersubjective process. One that depends on at least two instances to 
occur. And so, if we want to be equipped with tools capable of clearly discerning what is fake news and what is not, for example, we need to ask audiences how they feel about it.

The advice to read communication as an intersubjective process may seem innocuous and inefficient, but it dramatically changes the way we deal with mis and disinformation, especially when related to extremist messages and behaviors. The first effect of this change is the perception that the current scenario of disinformation cannot lead us to underestimate audiences. There are certainly those who share fake news not because they were naively deceived, but because those pieces align with these people's worldview. Furthermore, if a particular message needs to reiterate its intention, this is probably a sign of a deviation in the communicative process. This deviation means that either the message was not clear enough and therefore generated some misunderstanding or it was rearticulated and consequently had its original meaning altered and reframed in spite of the recipient. Roughly speaking, if someone says that it was just a joke, either the joke was not well placed in its metadiscursive character and therefore was never completed, or it was never really a joke. Or is a bad joke or something that was never meant to be funny. It remains to understand how to establish the benefit of the doubt for those who really wanted to but for some reason did not succeed.

Iterated analysis of interactions can help to resolve this issue. If something was a joke but, for a number of reasons that are not detailed, it could not be interpreted as such, reviewing the attitude of the joke-teller after they are challenged, expressed by an eventual and sincere apology, will suggest regret. On the other hand, the insistence on justifications that normalize oppression constitutes a second (and cruel) intention. In all the episodes I reported above, the appeal to justify that it was just a joke was not followed by a retraction, but, on the contrary, they were mostly followed by an attempt to evade public sanction. Further, criticism about the victims often remains: you have no sense of humor, or political correctness ruined the joke, "because it creates a fear of saying things" (that is, a fear of exercising domination through play). As President Bolsonaro has said, time has come to "free the people from socialism and the politically correct."

Humor and playfulness have been weaponized by extremist groups but they are in no way a recent development. Under the guise of good-natured criticism, it is possible to build scenarios that encourage public opinion to take certain positions or simply demobilize. Similarly, humor acts to build stereotypes that detract or diminish certain characters. It is good to remember that one of the primary objectives of campaigns to disseminate fake news is to delegitimize and attack political opponents. The ridicule works for the negative campaign taking the form of a harmless joke, and the diffusion of these humorous contents by the users provides an apocryphal action that is hard for authorities to regulate.

Understanding who the acid satire is aimed at and what intentions are behind it is not a task merely concerning the debate on media literacy. It relates to a much deeper approach to public life: the 
democratic character of play. There are those who say that humor necessarily oppresses, deludes and alienates. I think a democratic humor is possible, humor whose jokes are able to make you laugh without belittling, respecting individualities and identities.

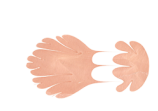

\section{Facticity}

"People believe in fake news when they seem to be real." This is a quote from Nelito Fernandes, one of the creators of Brazilian humorous fictional news site, the Sensacionalista [Sensationalist], in an interview, in 2016. It suggests the importance of the format and of the verisimilitude to the content we usually perceive as fake news. And it is no way isolated. It refers us to the proper definition of fake news according to Allcott and Gentzkow, not only as "news articles that are intentionally and verifiably false and could mislead readers" but also as "articles that originate on satirical websites but could be misunderstood as factual, especially when viewed in isolation".

By including satirical news in their own definition of fake news, they call attention to the appearance of the content, despite the writers' intention. In other words, matters that do not necessarily have factual basis but are presented as news, in an almost Machiavellian way, can be interpreted as "real" news. Understanding fake news by analyzing its appearance leads to a couple of concerns over its format. In practice, disinformation-rich content largely try to emulate news format or inspire the quality of truthiness for audiences, as Stephen Colbert once described it.

Quoting Claire Wardle, Chinese-American researcher An Xiao Mina suggests that fake news can anaphorically serve to punk, to provoke, to politicize, to profit and to polarize. And there are in fact a series of definitions, such as those also quoted by Chris Vargo and his colleagues, in which fake news could be understood as false information created for the purpose of financial gain or simply to maximize the attention directed at them. But understanding how they do it is critical to better analyzing this economy. Wayne Journell, for example, will say that fake news takes advantage of an illusory truth effect, in which users perceive messages that they seem to have read or heard before as more credible. Therefore, the circulation of disinformation is never based on a single piece of content. The same goes for jokes. It is necessary to create an environment favorable to the message, which, for example, involves the creation and maintenance of a certain climate of opinion, built upon a message ecosystem which develops a specific frame and gives an impression that the subject is familiar with. As Whitney Phillips argues, the emphasis on the term fake news is perhaps mistaken, since it would be 
more appropriate to designate this phenomenon as folk news, such is the relationship with common sense and popular culture that these contents seek in some measure to establish.

In practice, as Brazilian professor Luis Felipe Miguel sustains, even the traditional media can act as an auxiliary line for the disinformation network, as they help to build imagery on certain issues and actors. He highlights, for instance, the role of traditional media in spreading a polarized environment and fostering a climate of antipetism in Brazil, that is, an atmosphere characterized by intense animosity against the center-left Workers' Party (PT) and its suppotters. This climate would be further explored by fake news that circulated false accounts such as the involvement of the son of the former President Lula with the Friboi food brand, then facing a corruption scandal, in which the Friboi company was being investigated for selling rotten meat to people. One of its owners was also caught in leaked recordings of phone conversations with former President Michel Temer trying to pay other politicians hush money. But Lula's son never owned or had any relation with the company.

In addition, disinformation networks have a diverse model of operation on different social platforms. It is important to pay attention to the fact that the digital architecture of some platforms can influence the way in which disinformation is disseminated through them. In other words: fake news that circulate on Facebook or Twitter, or on 4chan and YouTube, are not necessarily the same as those circulating on WhatsApp or other platforms. Americans usually don't pay much attention to WhatsApp, as it is not nearly as popular among their population as it is in Brazil. But, on WhatsApp, its opaque environment does not allow the identification of a message's trajectory. This is one of the main factors that favor the highly ideological content of the messages that circulate there.

In Brazil, zero-rating policies sponsored by phone companies and the deep digital divide, fostered a scenario in which lots of people have internet access solely via their mobile phones. This makes WhatsApp a privileged means of communication, either for social interactions or for work. Most research on this platform suggests that the instant messaging application serves as a kind of a hub for other informational sources, such as conspiracy youtubers and bloggers. In this way, there is a hybrid media ecosystem - to use the expression coined by Andrew Chadwick - committed to disseminating disinformation and ideological content, and often with integrated action and content produced just-intime, that is, to respond to certain political events. What we have is an influencer like the conservative philosopher Olavo de Carvalho being called upon to produce a quick response on a one-minute YouTube video, which will then gain intense circulation on WhatsApp and soon become a meme on Twitter.

Memes, by the way, are a very useful format for disinformation networks, especially due to their ability to condense satirical messages in a small space and the relative ease of production, notably through the use of common templates and visual elements, the so-called templatization of messages. 
At this point, it is important to say: not every meme is fake news, but every fake news seeks to appropriate a spreading dynamics to rapidly gain evidence.

\section{Templatization}
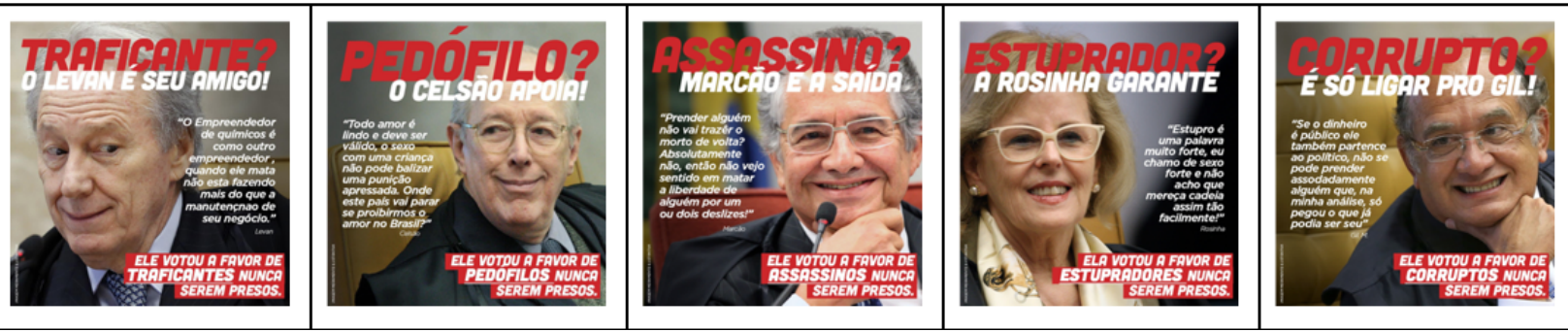

Figures: WhatsApp memes accusing five judges from Brazilian Supreme Court of defending criminals. All the memes circulated in groups of Bolsonaro's supporters, and each one associates one judge with a kind of a crime (respectively, drug dealing, pedophilia, murder, rape, corruption). All memes present the very same template.

Source: coLAB Research Laboratory database.

Beyond this, memes and fake news do have other common elements. Limor Shifman, for example, defines memes as a group of digital items, usually_produced with knowledge of each other, and put into circulation by users on social media. Like fake news, memes do not work in isolation. A single image with a caption, a single video with a parody is not able to define a meme. It is necessary to look at this phenomenon in a conjunctive way, that is, to put it in context, to see how they work to build a climate of opinion.

An episode that reflects Shifman's definition of memes is the case of the attempted murder of Jair Bolsonaro in September 2018. During the 2018 elections, then-candidate Bolsonaro was attacked by a man with a knife during one of his rallies. The man, Adélio Bispo, was diagnosed with mental disorder. Shortly after Bispo stabbed Bolsonaro, a series of conspiracy theories emerged. The most famous of them tried to link the criminal to the then-deputy Jean Wyllys, avowed opponent of Bolsonaro. Fake news reporting that Wyllys would have made payments of great amount to Bispo reinforced this theory. Right after that, Wyllys was already qualified as "suspect" by some influencers, and soon afterwards numerous montages began to circulate with the insertion of Adélio's image in meetings and rallies of left-wing politicians. At that time, former President Lula was one of the main opponents of Bolsonaro's candidacy. Even though he was on trial for an accusation of corruption, the whole process was controversial and a large amount of Brazilian population believed and still believe that Lula was being politically persecuted. For this reason, the former president sought to form alliances with leftwing candidates, hoping to run for election against Bolsonaro himself or to designate another candidate to run in his absence, which ended up occurring when Fernando Haddad was nominated by the Workers' Party. The far-right, then, tried to associate the image of Lula and several other possible 
candidates of the left to Adélio Bispo, in order to suggest a connection between these individuals. Everything was done through a series of photo montages, which interposed the attacker in different situations with leaders of the left. The corresponding footage was similar to others in which former president Dilma Rousseff was portrayed as a child alongside Adolf Hitler, as if to suggest he was a Nazi sympathizer.

\section{Fake news as an ecosystem}

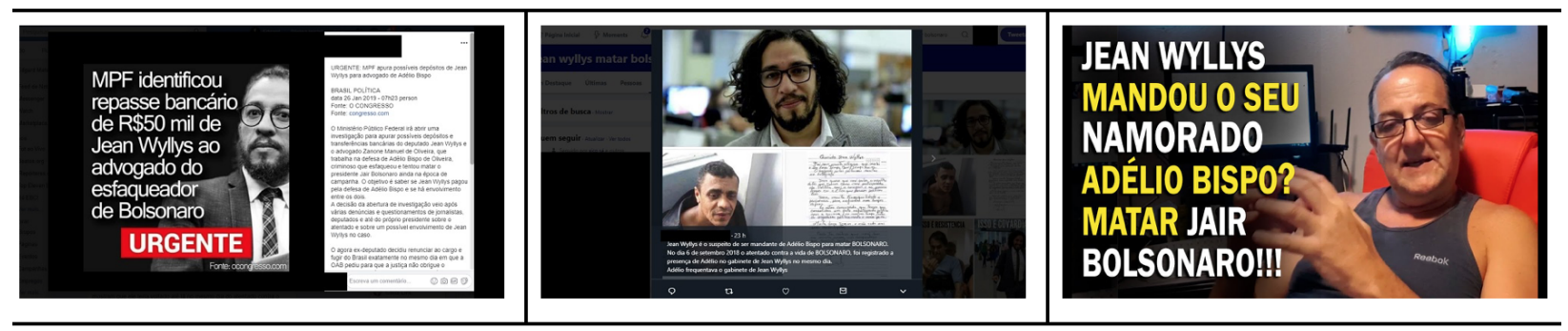

Figures: Different digital contents associating former deputy Jean Wyllys with Bolsonaro's attacker. One can read, in the first, that Public Prosecutors identify that the former deputy sent money to the criminal; that the former deputy is "suspected" of being the mastermind of the crime; and that deputy and criminal were lovers. All false information. Source: coLAB Research Laboratory database.

\section{Fake exploitables}

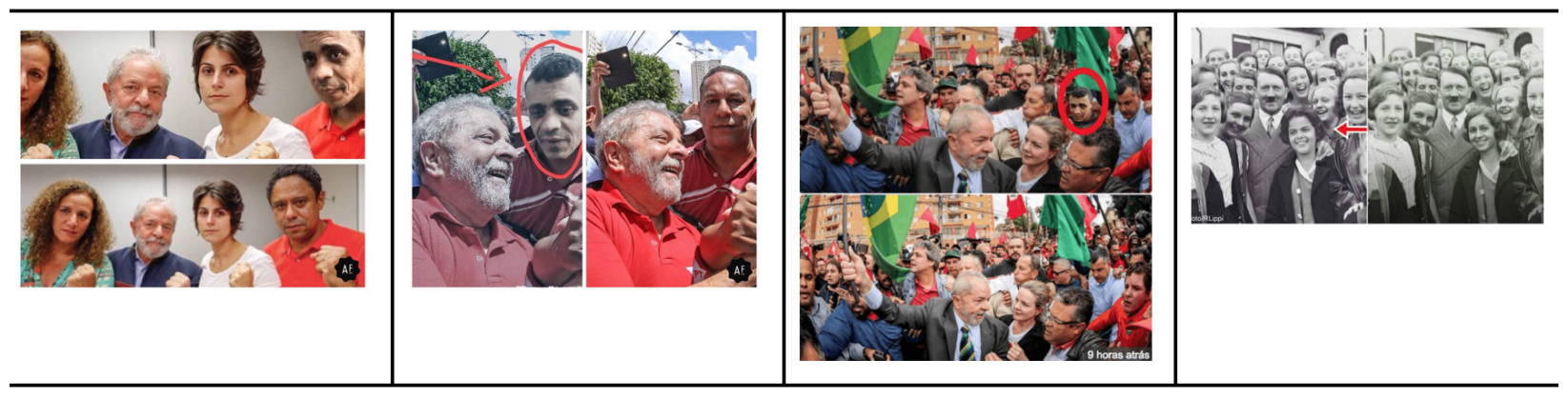

Figures: Different digital footage showing fake scenes. In the first three, Bolsonaro's attacker is seen side by side with opposition leaders, specially former President Lula. In the last, former President Dilma Rousseff is seen as a child with Adolf Hitler. All false images are compared with the real ones.

Source: coLAB Research Laboratory database.

Jean Wyllys was the victim of several other false accusations during that same campaign, including one that suggested that Workers' Party's candidate Fernando Haddad would have invited him to be Minister of Education if he won the elections. Wyllys, a notorious advocate for LGBTQ causes, would thus serve to associate Haddad's candidacy with another semantic set of fake news, the so-called "gay kit". The "gay kit" package was based on an alleged information that left-wing government would distribute some booklets to schoolchildren with incitement to so-called "genre ideology". Another related falsehood was the surrealist news that the government would distribute a baby bottle with a 
penis instead of its beak. Looking at this set is enlightening, as it illustrates how disinformation cannot be combated by focusing on isolated content. It is useless to limit the circulation of a meme or a joke if that same imaginary continues to be fed in other ways.

\section{The infamous gay kit and the penis baby bottle}

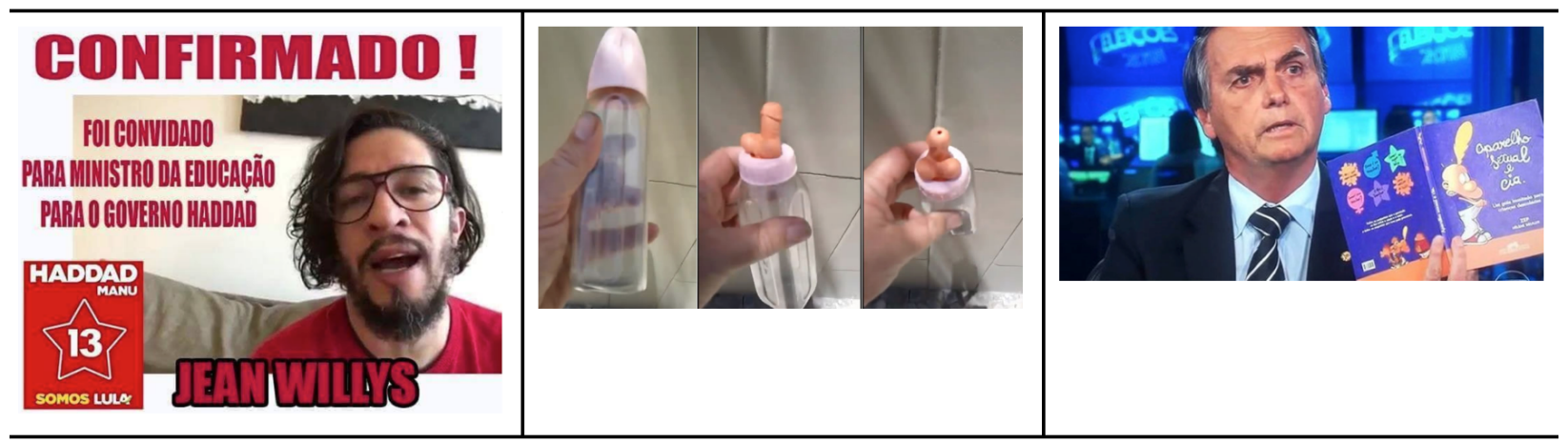

Figures: The first meme suggests that the name of former deputy Jean Wyllys was confirmed to be the future Minister of Education if candidate Fernando Haddad won the elections. The second meme shows a baby bottle with a dildo instead of its beak. Rumors had it that this nonsense object was to be distributed in schools by the Workers' Party government. The last image shows thencandidate Jair Bolsonaro during a televised interview showing what is accused to be a "gay kit" by far-right supporters. The booklet is a sex education material to be distributed to professors (not students) in order to guide them on questions that the children

Source: coLAB Research Laboratory database.

Furthermore, as Shifman once again recalls, memes are always messages that correspond to a specific form, content and stance. Therefore, as Wayne Journell assesses, memes are efficient vehicles for fake news, since they appeal to users' pre-existing beliefs, plant ideas and reinforce a certain sense of identification within specific groups, against which it is always difficult to act. Often, attempts to combat the spread of fake news backfire, because they act specifically against the form or content of a message, without paying attention to the fact that the stance is a direct result of a climate of opinion previously constituted around that subject. It is something similar to what Herman Wasserman says about the moral panic surrounding fake news in South Africa. The researcher draws attention to the fact that efforts to educate audiences for media literacy in order to improve the subjects' capacity for critical discernment have insisted on propaganda about the status of traditional journalistic media as guardians who hold the truth, without paying attention to the need to establish a dialogical experience capable of penetrating this imaginary and demystifying it. The big problem is that much disinformation seeks to emulate precisely the rhetorical or visual characteristics of the news format. 


\section{Fake headline}

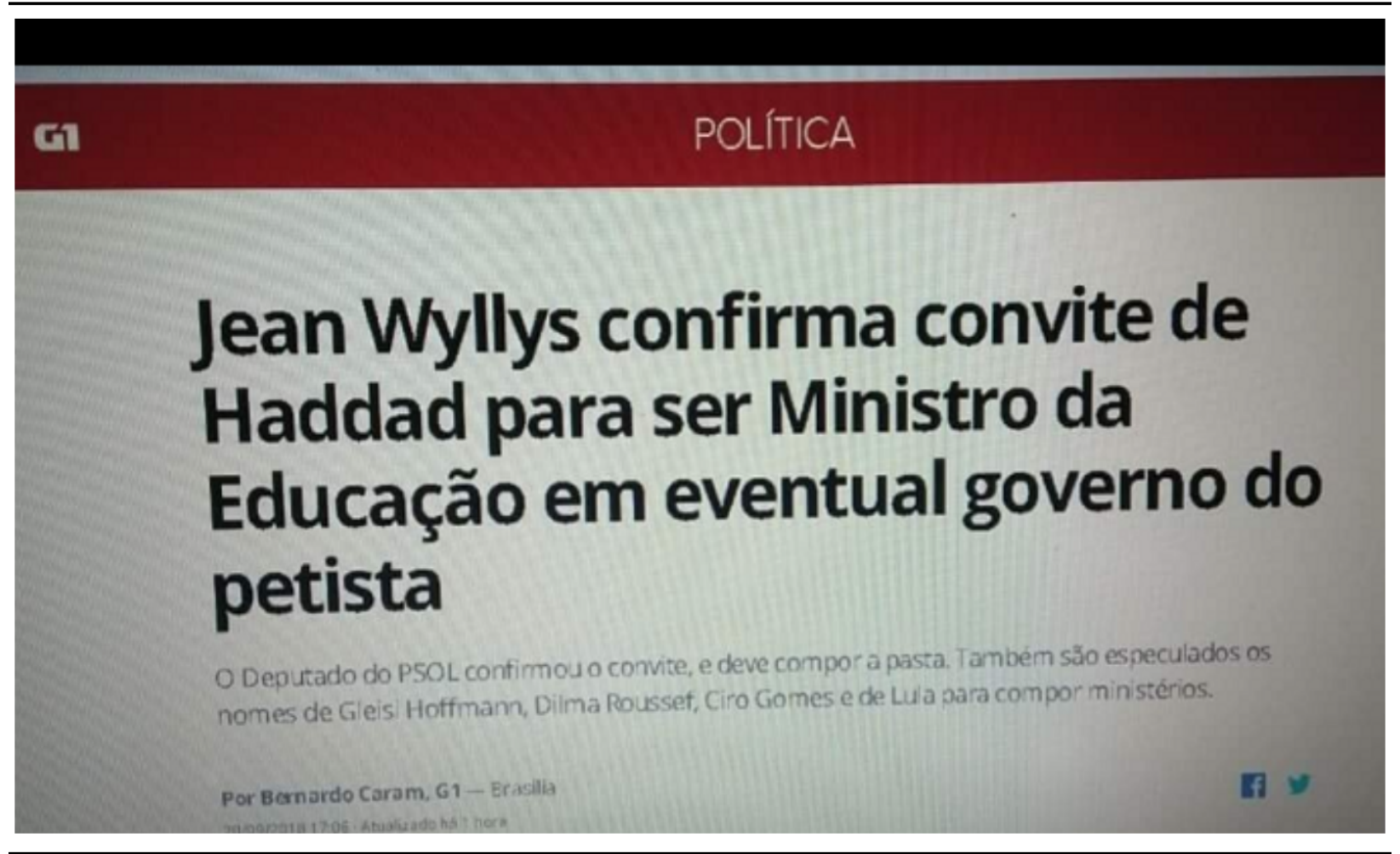

Figure: A fake headline from the mainstream journalistic website Gl alleges that former deputy Wyllys was confirmed to be the Minister of Education. The headline in fact never existed and the information is false.

\section{Source: coLAB Research Laboratory database.}

In this image, for example, everything indicates that it is a screenshot of Brazilian news website Gl, which gives immediate credibility to the information, which, however, is untrue. This case raises the question: How should we deal with content that visually embodies all the characteristics of real news? 


\section{Decontextualized information}

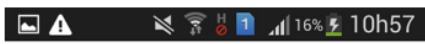

9 https://www.google.co 20 :

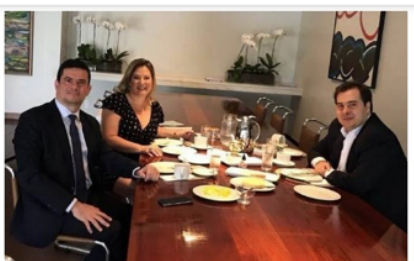

Foto: Divulgação

Sérgio Moro e Rodrigo Maia 'selaram a paz' em um café da manhă promovido pela deputada Joice Hasselmann

O Ministro da Justiça e

Segurança Pública, Sérgio

Moro se encontrou com o

presidente da Câmara dos

Deputados, Rodrigo Maia,

para um café da manhã. A

Figure: A true headline and image showing former Minister of Justice Sergio Moro having breakfast with the President of Lower Chamber Rodrigo Maia and deputy Joyce Hasselmann. Hasselmann is a former ally who fell out with Bolsonaro. Maia is a centerright deputy with whom Bolsonaro has fallen out with a few times also. The image gives the impression that the meeting occurred

just after Moro's resignation to his position. But in fact, it occurred one year before, when all of the three were still aligned with Bolsonaro's government.

Source: coLAB Research Laboratory database.

In another recent case, information circulated that former Minister of Justice Sergio Moro was caught having breakfast with two opponents of the President of the Republic, President of the Lower House Rodrigo Maia and deputy Joyce Hasselmann. When Moro was in charge at the Ministry of Justice and Public Security, he was sent to negotiate with congress several times, in order to approve what was being called the "anti-crime" laws. Moro was notable for being the judge who sentenced former President Lula to prison. Soon after, he was appointed by Bolsonaro to the Ministry, in one of the most controversial actions of the immediate post-election period. Sergio Moro, however, left the government claiming that Bolsonaro intended to intervene in the federal police on behalf of his allies in a case that had recently compromised the government. As a result, supporters of the president started a disinformation campaign, suggesting that the former judge had betrayed Bolsonaro. The claim was that the three, Moro, Maia and Hasselmann, were involved in a conspiracy against the government; Moro's resignation, along with the now-infamous breakfast, would be evidence of this. The breakfast actually took place and was widely reported in the press. But it was on March 2019, more than a year before Sergio Moro's resignation. In this case, therefore, the disinformation content is anchored in news extracted from traditional media, but presented out of context.

These are not the only strategies for lending credibility to disinformation. Another very common artifice in videos and audios is first-person narrative. It is usually an ordinary citizen who speaks into their cell phone cameras, in a tone of denunciation. In the video below, one can notice that the speaker 
is at the front door of a public hospital suggesting that the covid-19 pandemic is an exaggeration, as he had supposedly talked to some doctors and nurses who told him that the hospital was almost without patients. No conversation between him and any other person is filmed. The video never shows anything close to what he is alleging. On that very same day, the mayor of the city sent images of hospital beds completely full to the press. Nonetheless the video circulated heavily on private networks, spreading disinformation. Although its images do not contain any evidence, the speaker or sometimes the caption that accompanies the video in the instant messaging applications obscured the contradictions. First-person rhetoric aims to make the message indisputable, since the speaker, whoever he is, is able to attest what he supposedly saw or witnessed. Personal reporting is always a strong component of these messages.

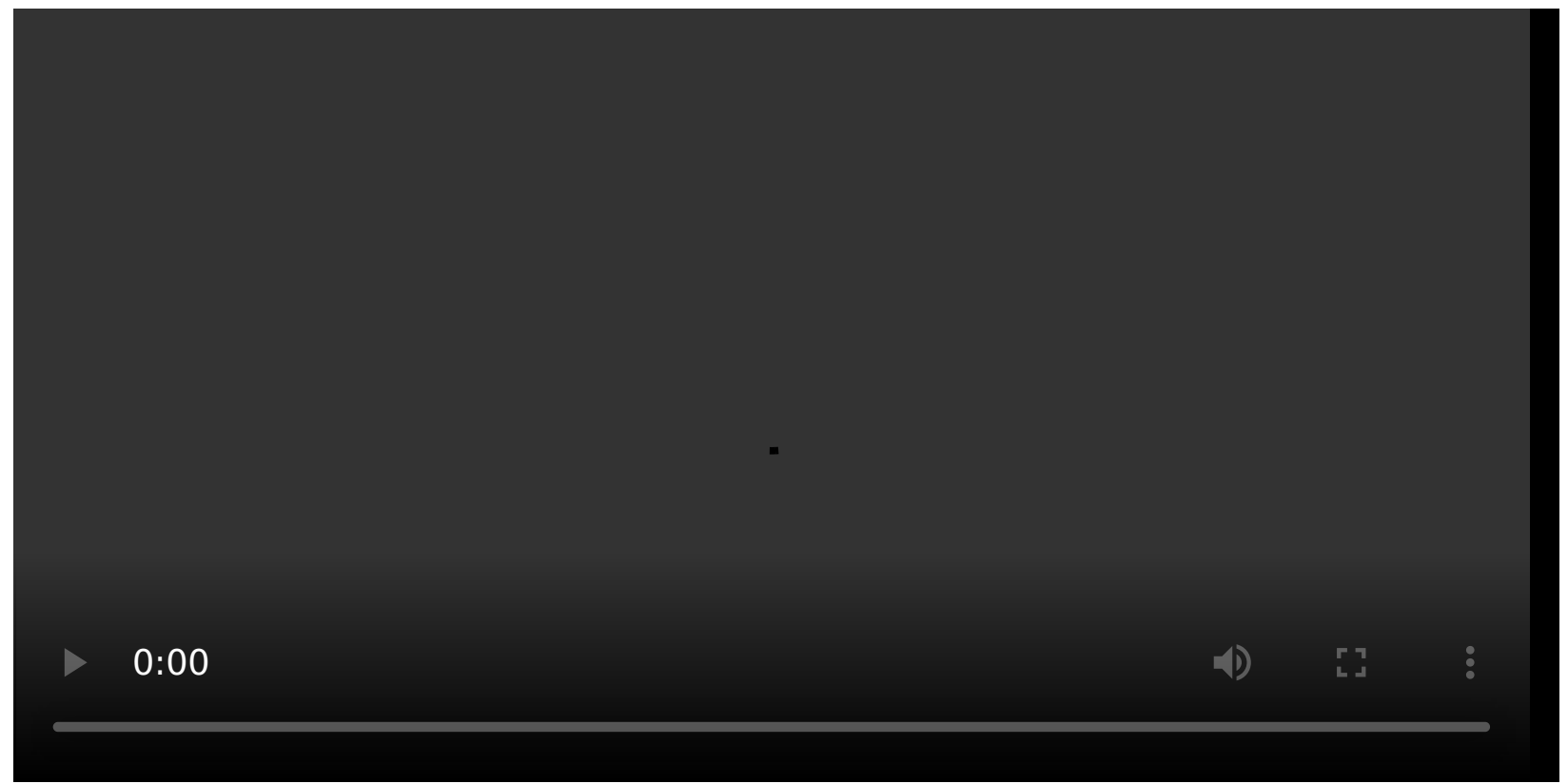

First-person POV and denouncing rhetoric

Video: A speaker says that he is in front of a public hospital and that there is no burden due to the pandemic. The images do not show any evidence that he is saying the truth but the denouncing tone denotes some urgency and intends to mobilize people against the social isolation measures recommended by health authorities.

Source: coLAB Research Laboratory database. 


\section{The mask of the beast}

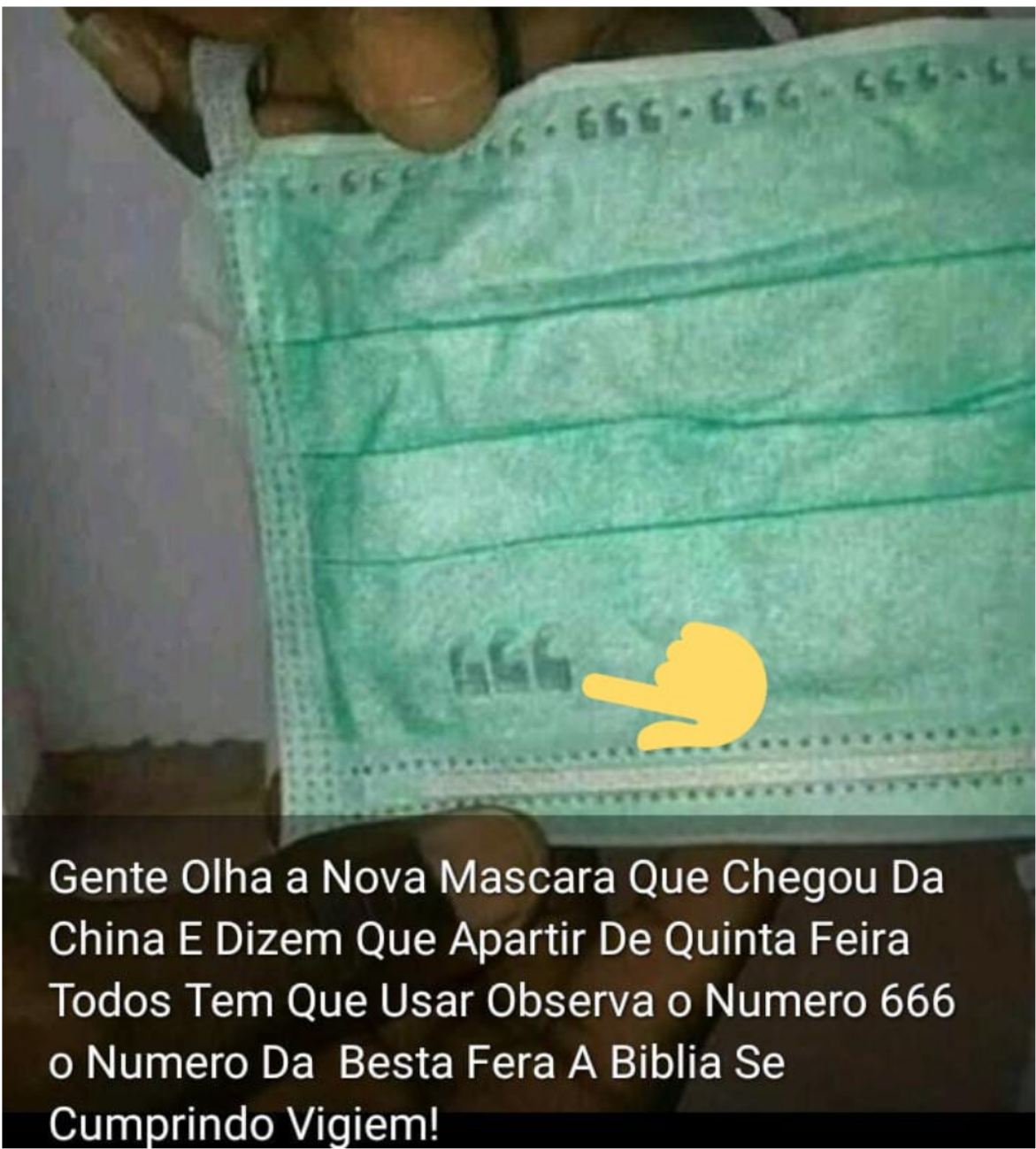

Figure: A person holds a surgical mask while the subtitle affirms that it has just arrived from China and has the number of the beast (666). In fact the photo is a Nigerian one, and the pattern has nothing to do with the alleged number.

Source: coLAB Research Laboratory database.

In summary, use of first-person point of view, narratives rich in detail, short and appealing taglines such as URGENT! or CONFIRMED!, requests for the message to be spread to as many people as possible, attacks on political opponents, and satirical and ferocious humor are some of the patterns that help spread disinformation on online platforms. Add to that the fact that these messages never act in isolation from a single piece; they are always put into circulation in a systemic way that takes into account the affordances of each platform and the specific features of the audiences to which they are designed. The result is to develop a truth effect and a sense of belonging that fosters the reproduction of the whole system. 
In the digital environment, disinformation takes on different formats and stances. But there is a striking feature common to all of them, the fact that they all pretend to be true. Whether because they emulate journalistic rhetoric or technique, or because they seek to inspire audience credulity, fake news is usually created in order to appear real. How then do we face this monster? I would say that media literacy is one of the possible solutions. Knowing how to read information critically, searching for similar images to identify possible montages, recognizing what and whom do a certain defamatory message serves, and many other guiding principles can somehow be useful. But, as Whitney Phillips points out in her Media Literacy Toolkit introduction, there is no point in teaching how to fact check information if one does not know exactly when and what information needs to be checked. Media literacy, therefore, is just an initial approach to an even more nebulous and complex scenario, which is political literacy.

Politics has recently become a subject of extreme popularity for Brazilian citizens. People who had never before in the history of the country followed the news so closely, today consider themselves experts in politics. Much of this sudden turn concerns the successive crises that the country has been experiencing. But this change in behavior was also consolidated by the memes and jokes passed on among people. There is, of course, a serious problem in all of this. When people who have never had free access to the public debate start to discuss politics based on such humorous and shallow content, chances are that this discussion will take place on a superficial and not very critical level. On the other hand, memes have been the gateway to substantive, critical public debate for many of these people. It would be inelegant to criticize these vehicles for the simple fact that they are not able to provide all the answers - which no other vehicle has ever been able to, either. The problem, then, in my view, is not to throw the baby out with the bath water, but to ensure that citizens are able to continue to contribute to public debate in an increasingly consistent manner. Therefore, the lessons that remain are twofold. We need to look not only at the communicative process, but also at the metacommunicative one. People must bear in mind that intersubjective relations depends on mutual agreement. There is no way to perform a joke if one of the sides feels embarrassed or oppressed by it. Also, we have to account that communicative processes are not made of one single message. We must not only observe the text, but also the context, that is, the constitution of imaginaries and a certain climate of opinion. This is a longterm literacy process, but nobody learns to read overnight. 


\section{Acknowledgments}

I would like to sincerely thank dear friend and colleague Whitney Phillips for all support, especially the generous reading and insightful comments. I would also like to thank Nina Santos and João Senna for encouraging me with the very first draft of this essay.

\section{References}

Allcott, H., \& Gentzkow, M. (2017). Social Media and Fake News in the 2016 Election. Journal of Economic Perspectives, 31(2), 211-236.

Bateson, G. (1955). A theory of play and fantasy. Psychiatric Research Reports, 2, 39-51.

Chadwick, A. (2013). The Hybrid Media System: Politics and Power. Oxford University Press.

Chagas, V. (2020). Dolce farmeme: a retórica da brincadeira política [Dolce farmeme: the rhetoric of political play]. XXIX Compós Conference, Proceedings of.

Chagas, V., \& Freire, F. (2018). Quando o jornalismo político é uma piada: análise do conteúdo político do Sensacionalista e sua repercussão em mídias sociais [When political journalism is a joke: analysis of political content of Sensacionalista and its repercussion in social media]. Rumores, 12(24), 271292.

Goffman, E. (2002). Footing. In: Ribeiro, B. T., \& Garcez, P. M. (eds.). Sociolingüística interacional [Interactional sociolinguistics]. Loyola, pp. 107-148.

Goffman, E. (1986). Frame Analysis: An Essay on the Organization of Experience. Northeastern University Press.

Hirschman, A. O. (1991). The Rhetoric of Reaction. Belknap Press.

Journell, W. (2019). Unpacking fake news: an educator's guide to navigating the media with students. Teachers College Press.

Miguel, L. F. (2019). Jornalismo, polarização política e a querela das fake news [Journalism, political polarization and the quarrel of fake news]. Estudos em Jornalismo e Mídia, 16(2).

Mina, A. X. (2019). Memes to movements: how the world's most viral media is changing social protest and power. Beacon Press. 
Phillips, W., \& Milner, R. (2017). The Ambivalent Internet: Mischief, Oddity, and Antagonism Online. MIT Press.

Phillips, W. (2020). Navigating the Information Landscape: A Media Literacy Toolkit Series . Commonplace. https://doi.org/10.21428/6ffd8432.37155cc8.

Shifman, L. (2014). Memes in Digital Culture. MIT Press.

Tandoc Jr., E. C., Lim, Z. W., \& Ling, R. (2017). Defining “Fake News”: A typology of scholarly definitions. Digital Journalism, 6(2), 137153.

Vargo, C. J., Guo, L., \& Amazeen, M. A. (2017). The agenda-setting power of fake news: A big data analysis of the online media landscape from 2014 to 2016. New Media \& Society, 122.

Wasserman, H. (2017). Fake news from Africa: Panics, politics and paradigms. Journalism, 5(1). 